\title{
Hepatitis C Virus: An Alarming Global Threat
}

\author{
Irshad Ahmad* \\ Department of Life Sciences, King Fahd University of Petroleum and Minerals, Saudi Arabia
}

Submission: February 01, 2017; Published: March 08, 2017

"Corresponding author: Irshad Ahmad, Department of Life Sciences, King Fahd University of Petroleum and Minerals, Saudi Arabia, Tel: +96638607032; Fax: +96638604277; Email: irshad@kfupm.edu.sa

\section{Opinion}

Hepatitis C virus (HCV) is an envelope, positive-sense, singlestranded RNA virus which belongs to the genus Hepatits c virus and family Flaviviridae. It is a major cause of liver disease and in the long run proceeded to liver cirrhosis, hepatocellular carcinoma and liver failure eventually because death of the patient. HCV is an alarming epidemic that has infected more than 200 million people worldwide. Highest prevalence of HCV has been reported in the developing countries of the world especially in the subcontinents of Africa and South Asia. HCV shows a significant genetic diversity and has several strains or genotypes which vary among different geographic regions. A higher prevalence of HCV infection has been reported recently as 14.7, 6.7, 4.4, 3.2, 2.3, 2.3, 2.2, 1.5, 1.3, 1.3 and 1\% in Egypt, Pakistan, Taiwan, Iraq, Philippine, Malaysia, Yamen, India, China, Japan and Turkey respectively.

HCV is blood borne virus which is commonly transmitted through injectable tools used for drugs, using unsterilized medical equipment's for surgical operations, particularly syringes and needles used in medical settings, piercings needles used for tattooing, transfusion of unscreened blood and blood products. The occurrence of hepatitis in most people is contributed by lack of awareness, increased and repeated use of contaminated razors, syringes, scissors, towels and keeping sexual relationship with HCV-infected partners. The problem in the developing countries become worse due to this silent epidemic as most of the people actually do not know about their hepatitis status. Due to the unavailability of proper hepatitis testing tools the patients usually get delayed treatment. Moreover due to their low socioeconomic conditions most of the patients are unable to continue the expensive antiviral treatment. Compared to other infectious diseases like malaria, HIV and TB, HCV is not considered as a serious threat by global funding agencies. Additionally the severity of HCV is poorly understood by many countries due to the lack of resources for the hepatitis prevention programs.

In these scenarios it is the responsibility of the developed nations to strengthen and develop collaboration links with the developing countries that are severely infected by this epidemic. To achieve this noble cause World Health Organization (WHO) can play a vital role to provide technical support to the infected countries in order to assist them to develop and implement programs for HCV awareness, prevention and diagnosis and ensure treatment facilities for the common people.

\begin{tabular}{l} 
Your next submission with JuniperPublishers \\
will reach you the below assets \\
- Quality Editorial service \\
- Swift Peer Review \\
- Reprints availability \\
- E-prints Service \\
- Manuscript Podcast for convenient understanding \\
- Global attainment for your research \\
- Manuscript accessibility in different formats \\
( Pdf, E-pub, Full Text, audio) \\
- Unceasing customer service \\
Track the below URL for one-step submission \\
https://juniperpublishers.com/online-submission.php \\
\hline
\end{tabular}

